\section{E-Rate under fire}

By the close of 2000 , the E-Rate, which provides telecommunications service discounts to schools and libraries, enjoyed widespread support among many legislators, telecommunications industry leaders, and the public. However, there were still those who introduced legislation to eliminate or restructure the program, which provided $\$ 3.65$ billion in discounts during its first two cycles to libraries and schools for basic telecommunications, Internet access, and internal wiring. All of these bills remained pending by the end of the second session of the 106th Congress.

In February, the Bush Administration introduced proposals to move the E-Rate program into a block grant with other technology programs in the U.S. Department of Education. It is unclear how libraries would be treated in the new program if it should happen. Some fear libraries may even be cut from the program. There is also at least one congressional proposal from Rep. Gene Green (D-Texas) that would latch onto allegedly uncommitted E-Rate funds to provide school computer labs with $\$ 25,000$ grants.

The E-Rate has provided a large number of libraries with the ability to improve telecommunications services for patrons. But many librarians are unaware of the benefits offered by the E-Rate. Following are some key facts about this invaluable program:

- The E-Rate is a federal initiative that expands and updates this country's longstanding national policy goal of Universal Service by providing discounts on telecommunications and Internet-related technologies to schools and libraries.

- The E-Rate program is administered by the Federal Communications Commission (FCC), where it has prospered by providing a secure, reliable, and equitable source of continual funding to connect libraries and schools to discounted Internet-related services.

Lynne E. Bradley is Office of Government Relations director of ALA's Washington Office; e-mail: leb@alawash.org
- The E-Rate program was one of the few and very important public interest provisions in the Telecommunications Act of 1996. Part of the reason the E-Rate is in the Universal Service program is that it was part of the bargain for major deregulation of the telecommunications industry, which the providers wanted at the time the act was passed.

- The E-Rate program is locally controlled, community based, and accountable-allowing each school and library that applies for E- Rate funding to design a system that works best for them.

- The administration's current proposal will deny important financial resources to libraries, once again marginalizing access to Internet-related services to those poor and underserved communities that most desperately need and rightfully deserve them. Further, private and parochial schools would also be affected should the program be moved under the U.S. Department of Education.

- It has been affirmed in court cases and other analyses that Universal Service funds are not a tax. These are not funds that can be summarily moved from the purview of the FCC to the U.S. Department of Education, which functions with appropriated funds from tax revenues.

- Discounts range from 20 to 90 percent (based on the poverty level in the local community), and schools and libraries are required to pay the non-discounted portion of the bill themselves. FCC funds the program up to $\$ 2.25$ billion annually, contingent upon demand. These funds are collected as part of the Universal Service contributions made by the appropriate telecommunications companies.

- The E-Rate discount program is playing a central role in bridging the digital divide by bringing new technologies and the power of the Internet to America's libraries and schools.

We need more academic librarians involved in these battles if we are to keep these important telecommunications discounts for our library users and our institutions. 


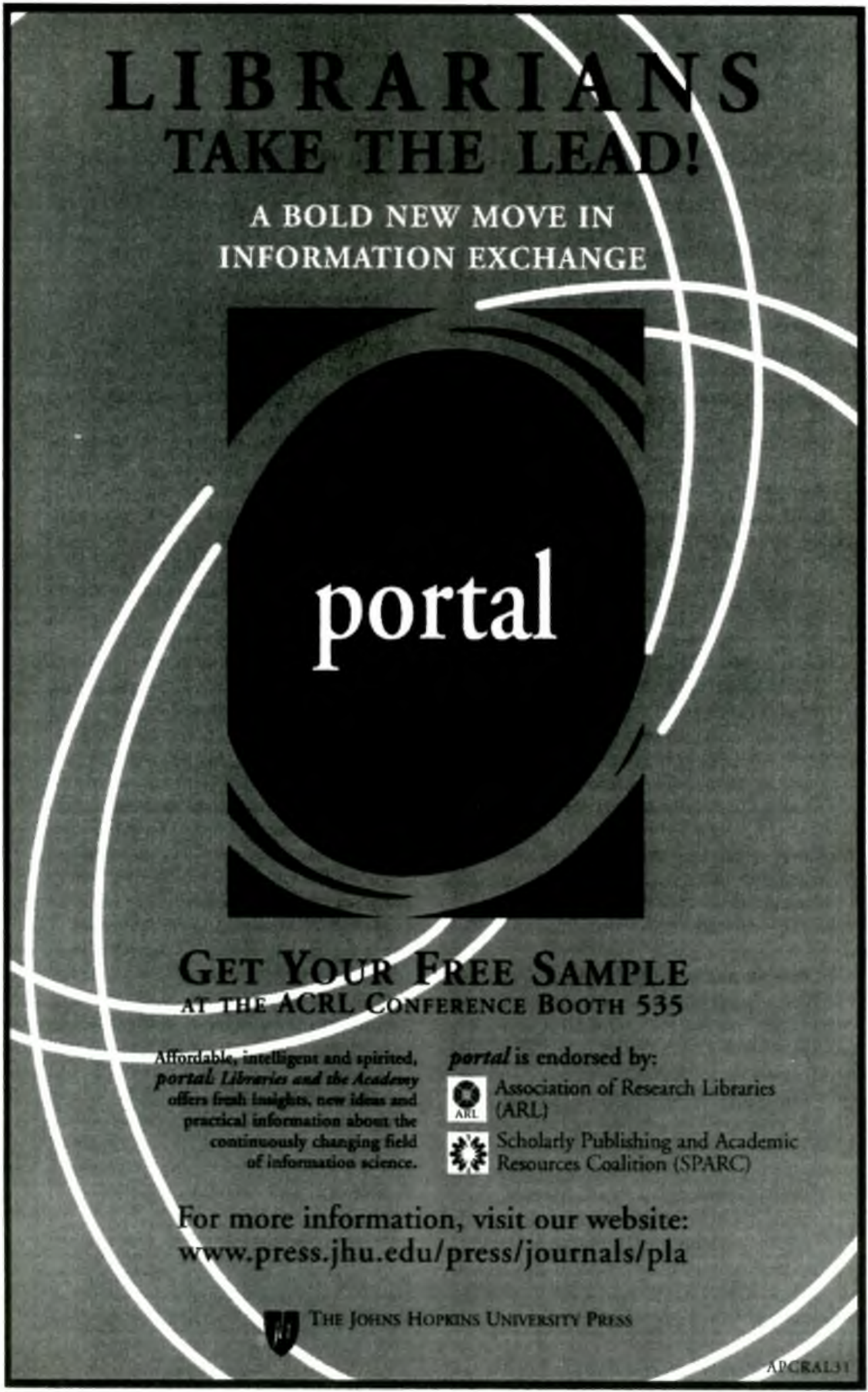

